\title{
Camino Soria
}

\author{
Soria way \\ Soria Caminho
}

Francisco Herrera-Rodríguez

Catedrático de Escuela Universitaria. Facultad de Enfermería y Fisioterapia (Universidad de Cádiz)

Cómo citar este relato en edición digital: Herrera Rodríguez, F. (2015). Camino Soria. Cultura de los Cuidados (Edición digital), 19(43). Disponible en:< http://dx.doi.org/10.14198/cuid.2015.43.04>

Correspondencia: Francisco Herrera-Rodríguez. Facultad de Enfermería y Fisioterapia. Avda. Ana de Viya, 52. 11009-Cádiz. Correo electronico: francisco.herrera@uca.

Recibido: 11/05/2015; Aceptado: 14/07/2015

\section{ABSTRACT}

Josep Pla taught us that life in all its dimensions fit in a bus, so the traveler looks at the trees in the way, but also the suffering and joyful hearts that accompany it. The stories he sees and hears are overwhelming, like Maria Zambrano said about Galdos' characters, except that here on the bus the traveler feels the devastation and the glory of life in the raw.

Keywords: Loneliness, heartbreak, alcoholism, drugaddiction.

\section{RESUMO}

Josep Pla nos ensinou que a vida em todas as suasdimensões se encaixamemumônibus, de modo que os ro viagemolhar para as árvores do caminho, mas também o sofrimento e corações alegres que o acompanham. As histórias que vêem e ouvem sãoesmagadoras, como Maria Zambrano dos personagensem Galdos, exceto que aqui no ônibus o viajante sente a devastaçãoeaglória de matéria-vida disse.

Palavras chave: Solidão, desgosto, alcoolismo, toxicodependência.

\section{RESUMEN}

Josep Pla nos enseñó que la vida en todas sus dimensiones cabe en un autobús, por eso el viajero mira a los árboles del camino, pero también a los corazones dolientes y alegres que le acompañan. Las historias que ve y escucha son arrolladoras, como decía María Zambrano de los personajes de Galdós, salvo que aquí en el autobús el viajero siente la devastación y la gloria de la vida en carne viva.

Palabras clave: Soledad, desamor, alcoholismo, drogadicción.

El autobús paró y se subieron varios viajeros, entre ellos una mujer con el pelo arruinado, la falda muy corta y penumbra de alcohol en la mirada. Se sentó cerca de mí y sacó el móvil tembloroso. Sola en su abismo empezó a leer en voz alta los mensajes que había recibido sabe Dios cuando. Al rato exclamó: «iEste! ¡Este es el que más me gusta!». Y leyó con voz rota: "Siempre supiste amarrarme con una mirada, con un beso o cogiéndome de la mano. Nadie me ha querido como tú. Me regalaste en Soria la noche más bonita de mi vida». Se calló, exhaló una bocanada de aire agrio, y con la serenidad de los triunfadores, con la seguridad de haber ganado la partida de su vida dijo: "iQué cabrón! Esto por mis muertos se lo mando a la Bego, para que vea que el mierda este me ha querido más que a ella». El autobús paró y se bajó como pudo dando tumbos. Los huesos dolían solo de mirarla. Caminaba en dirección a la noche, tecleando temblorosamente en su móvil. La perdí de vista y el autobús arrancó, y no sé por qué pensé en los olmos heridos de Soria, que reverdecen cada primavera, no se sabe si por desamor o por costumbre. 